\title{
The Impact Of Ownership Structure On Corporate Debt Policy: Two Stage Least Square Simultaneous Model Approach For Post Crisis Period: Evidence From Kuala Lumpur Stock Exchange
}

\author{
Huson Joher, (Email: halahmed@kaau.edu.sa), Curtin University of Technology, Malaysia \\ Mohd Ali, Universiti Putra Malaysia \\ Nazrul, Universiti Putra Malaysia
}

\begin{abstract}
Ownership concentration as a governance mechanism has received considerable attention among academician, practitioners as well as policy makers because large-block shareholders are increasingly active in their demands that corporations adopt effective governance mechanisms to control managerial decisions, which include corporate debt policy. Earlier study on the agency model of the firm widely recognizes that the managerial ownership and external debt play an important role in mitigating agency conflicts and enhancing firm value. They also found that increase in the external monitors, for example the institutional investors, can actually play a useful role in limiting agency problems in the firm. This paper, using 100 Composite Index companies from Brusa Malaysia between 1998 to 2002 explores the impact of institutional holdings on managerial ownership and debt policy in an integrated framework by using a simultaneous equations estimation procedure (2SLS). The findings show that there is a significant impact of institutional ownership which serves effective control mechanism on managerial ownership and corporate debt policy as hypothesized. Findings of such evidence suggest that institutional holding thus have played an important role in managers' strategic management decision and reduce agency conflict. In addition, corporate debt policy too is governed by managerial ownership and exhibited a negative relation.
\end{abstract}

\section{INTRODUCTION}

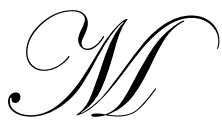

odern corporate finance literature focuses on two competing issues governing the management behavior. These are agency problem and theory of corporate control. Agency theory posits that there is an inherent conflict of interest between shareholders and managers because of the existence of separation of ownership and control. Ownership structure become increasingly important phenomena as it has important implication for firm performance and value by mitigating agency costs of the firm. More recently numbers of research have been documented on the impact of ownership structure on corporate debt policy because of their interdependency.

Therefore, two important goals of this paper include (1) the impact of corporate ownership on corporate debt policy and (2) factors determining the interdependencies of ownership structure and corporate debt policy. The use of OLS measure to estimate the interdependency between above relations may results bias estimation. In view of the concern about the consequence of using OLS, this paper uses 2SLS to estimate the relationship mentioned above. Hence the objectives of this paper are twofold. First we offer additional view that corporate ownership structure and 
corporate debt policy are interdependent. Secondly, we determine the impact of institutional ownership on both ownership structure of the firms and corporate debt policy during the period 1998 to 2002.

In Malaysia, the ownership concentration has been weak, compared to most developed countries. The institutional ownership accounts for less than 20\% of the outstanding shares (Huson, 2003). Ownership structure of a corporation is basically divided into three categories. These are institutional ownership, managerial ownership and individual ownership.

Institutional owners include pension funds, mutual funds, life insurance companies, trust departments of commercial banks, property and casualty insurance companies, closed-end funds, savings institutions, and commercial bankers. Normally they include the company's share as their portfolio investment. Though they are in smaller number, institutional investors control most of the "dollar votes" and have a larger impact on securities prices than the individual investors. Managerial ownership consists of directors, managers, and other management teams members, who hold the company's shares directly. The third group of investors is the individual owners. This group constitutes a major pie of total shareholding as compare to developed countries. Nonetheless, they do not control much of dollar vote. Hence no effective control mechanism could be placed on managerial decision making.

Recent innovations in the financial literature suggest that ownership structure and the distribution of financial claims can affect firm performance and value by mitigating agency costs of the firm. Though there is increasing empirical evidence on corporate control in developed market but little attention has been given Malaysia, to examine the impact of corporate control particularly institutional ownership on firms' debt policy. In view of diverse culture and shareholder pattern in Malaysia it will be unique to examine the impact of institutional ownership on insider ownership and corporate debt policy. The rest of the paper is organized as follows:- section two provides theoretical and empirical perspectives on ownership structure, and corporate debt policy. Section three briefly describes the data and methodology used in this paper. Findings, conclusion, and implication are presents in the section four.

\section{THEORY AND EVIDENCE}

The understanding the empirical differences in the pattern of corporate control has advanced in recent years. However, theoretical development in this area of research is yet limited. There is number of studies that attempt to explain theoretically why control is so concentrated with poor shareholders protection in a setting where alignment is the only viable mechanism of corporate governance (La Porta et al. 1999). La Porta et al. (2002) make the case for higher concentration of cash flow as a function of quality of investors' protection. However, the empirical evidences suggested three generic measures to control agency problem. These are aligning the managers' incentive with that of shareholders, monitored debt and take over threat.

According to the agency model of the firm espoused by Jensen and Mekling (1976), the modern corporation is subject to agency conflicts arising from the separation of the decision-making and risk-bearing functions of the firm. In this setting, Jensen and Mekling show that managers have a tendency to engage in excessive perquisite consumption and other opportunistic behavior since they receive the full benefit of such activity but bear less than their full share of the costs. Jensen and Meckling refer to this as the agency cost of equity and show that it could be mitigated by increasing managerial ownership in the firm, thus forcing managers to bear the wealth consequences of their actions. More importantly, the seminal work of Jensen and Meckling (1976), suggest that the managerial ownership could serve as a positive monitoring substitute in the agency relation in aligning the managerial interest with those of outside shareholders. They further argued that if there were no debt contracts, agency problem reduces to moral hazard between the manager and owners.

Managerial interests may prevail when governance mechanisms are weakly placed, as is exemplified by allowing managers a significant amount of autonomy to make strategic decisions. Ownership concentration as a governance mechanism has received considerable interest because large-block shareholders are increasingly active in their demands that corporations adopt effective governance mechanisms to control managerial decisions. 
While, diffuse ownership (a large number of shareholders with small holdings and few, if any, large-block shareholders) produces weak monitoring of managers' decisions. Diffuse ownership (individual owners) also makes it difficult for owners to effectively coordinate their actions. Higher levels of monitoring could encourage managers to avoid strategies decisions that harm shareholder value. In fact, research evidence shows that ownership concentration is associated with lower levels of firm product diversification. Thus, with high degree of ownership concentration, the probability is greater that managers' strategic decisions will be intended to maximize shareholder value. Much of this concentration has come from increasing equity ownership by institutional investors.

Numerous scholars have examined the performance of East Asian corporations over the last four decades, but ownership structure and the separation of ownership and control remain largely unknown. Several studies on corporate governance in Japan (Aoki, 1991; Prowse, 1991; Hoshi et al., 1991) point to the significance of keiretsu groups. These studies focus, however, on company performance, and do not attempt to trace the ownership of each company to its ultimate owners and identify those owners by type and control stake. The exception is Lim (1981) who studies in detail the ownership structures of the largest 100 corporations in Malaysia.

The literature on the theory of the firm suggests that debt policy may be useful in reducing agency conflicts. Jensen (1986) argues that, because debt "bonds" the firm to make periodic payments of interest and principal, thus, it reduces the control managers have over the firm's cash flow and the incentive to engage in non-optimal activities. Grossman and Hart (1982) similarly argue that the existence of debt forces managers to consume fewer perquisites and become more efficient as this lessens the probability of bankruptcy and the loss of control and reputation. However, too high a level of debt subjects the firm to agency costs of debt, especially in the form of a risk shifting incentive. Increase in debt essentially encourage firm to riskier projects. It is because firm can pay-off off the debt holders at the contracted rate and capture the residual gain if the projects are successful. However, if the projects fail, the bond holders bear the costs of the higher risk. The trade-off between agency costs of external equity and debt results in an optimal amount of debt and managerial ownership in the firm. In sum, the agency framework indicates that both debt and managerial ownership reduce agency costs of the firm and enhance firm value.

Fama and Jensen (1983) in their study conclude that increased ownership concentration (any kind of owner) decreases financial performance because it raises the firm's cost of capital as a result of decreased market liquidity or decreased diversification opportunities on behalf of the investor.

Berle and Means (1982) suggest the existence of positive linear relationship between ownership concentration (block shareholding or institutional investors) and firm performance. The issue was later advanced by Shleifer and Vishny (1986), and their result confirms the findings of Berle and Means (1982). Their findings highlighted the important role played by large shareholders as a monitoring device, to control management activities and hence increase the share price of the firms' by increasing the proportion of shares held by these large shareholders. Hill and Snell (1988) showed that ownership structure affect firm's performance as the ownership concentration motivates innovation that leads to value maximization. Hill and Snell (1989) also confirm this positive relation using US firms by taking productivity as a measure of firm's performance. However, the findings of McConnel and Servaes (1990) give contrary view, although their result suggests the existence of certain joint influence of concentration and insider ownership.

The functioning of a performance monitoring system, such as the public stock market, may depend on the ownership structure. For example, on one hand, extremely dispersed ownership may result in more speculative prices because of a lack of informed investors, but on the other hand an extremely concentrated ownership structure could also cause speculative prices because of too little market liquidity. Such distortions of market valuation may in turn result in a rise in the firm's cost of capital.

While debt and managerial ownership on the other hand may serve mitigate agency problems, the literature also recognizes that the extent to which these devices are utilized is determined by the existence of other internal and external monitoring mechanisms that hold managerial behavior in check. Jensen and Meckling (1976) discuss some of these mechanisms and their role in controlling agency conflicts. Internal monitoring mechanisms include competition among managers within the firm, auditors, and the board of directors. External monitoring mechanisms include the 
stock market and the takeover market. The literature recognizes that institutional investors serve a significant role as external monitors in the stock market (Agrawal and Mandelker (1990).

Institutional investors on the other hand are an important group of agents in the market for corporate equity, since they on average own 45 percent of the total market capitalization in the OECD countries. Besides being the largest group of investors they also account for a large fraction of the turnover on the stock exchange. Consequently, Institutional investors are an important component of a well-functioning market for corporate equity.

Over the past few decades, role of institutional shareholders in the listed companies has expanded manifold. It is also believed that institutional shareholders can be instrumental as agents of change towards improving corporate governance. Various studies have been conducted to explore the effectiveness of institutional shareholders in developed countries notably USA and UK. Using data for listed companies, this research work explores the institutional ownership pattern in Malaysia the listed companies. This paper specifically investigates the role of institutional shareholders in promotion of Corporate Governance.

The significance of institutional investors as monitoring agents is underscored by their sizable equity investments in the stock market. Historically, institutional investors dissatisfied with managerial or stock performance simply sold their holdings, that is, follow an "exit" policy. However this has become increasingly difficult to many institutions. Coffee (1991) provides an insight into the changing behavior of institutional investors from being passive investors to active monitors. He suggests that the trend toward increased activism on the part of institutional investors can be explained by the fact that exercising "voice" has become less costly because of the significant ownership of equity by institutions and the "resulting increased capacity for collective action;" at the same time, following an "exit" policy has become increasingly more expensive because they must accept substantial discounts in order to liquidate their significant holdings.

The increased activism of institutional investors is supported by their attempts to enhance managerial accountability through various means. Institutions have made increasing use of proxy contests to bring about fundamental changes in management behavior. These corporate governance proposals cover issues such as the repeal of classified boards, poison pills and other anti-takeover measures Agrawal and Mandelker (1990)), rescinding of golden parachutes, implementing confidential voting, changing the composition of boards, and executive compensation. Institutions also have pressured management into making the boards more independent through greater outside representation.

Finally, institutions have sought to increase their oversight on companies through the formation of shareholder advisory committees that serve to review operating and financial results of the company and seek to enhance dialog and the flow of information between major shareholders and management. According to the Wall Street Journal (1993), the California Public Employees Retirement System (CalPERS), for example, had pressured Pennzoil and Champion International to set up shareholder committees to monitor their financial performance. In other cases, institutions sought informal meetings to discuss business developments on a periodic basis (the Wall Street Journal (1993)).

Excessive managerial ownership of common stock may lead to entrenchment problems. Voting and takeover mechanisms can fail if managers posses the controlling interest in the firm. Also managers may be unwilling to invest too much of their personal wealth in the firm in order to avoid the increasing costs of non-diversification of their personal wealth. Significant use of debt financing may result in a substantial increase in the firm's bankruptcy risk and an increase in the non-diversifiable risk of bankruptcy to managers themselves. Additionally, agency problems, such as asset substitution or risk shifting and under-investment, may be exacerbated with high levels of debt financing. Even too much institutional ownership may have costs associated with it. Some have argued that institutional ownership increases stock price volatility, while others suggest that it induces short term myopia in management.

Given the costs and benefits to the different agency-cost-reducing mechanisms, managers are expected to optimize their usage such that the total agency costs in the firms are minimized. While managers have little control over institutional holdings of the common stock, they have the ability to manage the levels of inside equity ownership 
and debt financing. The substitutability arguments proposed above suggest that, as institutional ownership and the attendant monitoring increases, firms may find it optimal to utilize lower level of debt and managerial ownership to control agency conflicts in the firm.

\section{DATA AND METHODOLOGY}

\section{Data and Method of Estimation}

A sample of 100 firms most of which are drawn from Composite index (CI) component firms which serves as market barometer for the Malaysian stock price performance over the period 1998 through 2002 were studied. The proxies for corporate ownership and firm's performance are extracted from companies' annual handbook, companies' annual reports and many other sources such as KLSE-RIS. The choice of $100 \mathrm{CI}$ component companies may lessen the sampling bias as this serve as market barometer.

\section{Model}

A simultaneous equations approach particularly 2SLS is deemed to be appropriate on the basis of the interrelationships among the agency-cost-reducing mechanisms. This study uses a two-equation model with managerial ownership of equity and debt ratio as the dependent variables. Additional debt ratio appears as a regressor in the managerial ownership equation and vice-versa. Thus, the debt ratio and managerial ownership are simultaneously determined.

Along with other control variables, the proportion of institutional holdings of common stock is included as an explanatory variable in both equations. Institutional holdings are specified as an exogenous variable since they are external to the firm - which is out of management control and thus not a management decision variable. Managers are assumed to have control over the levels of debt and managerial ownership of equity in the firm; however, it is unlikely that managers can decide on a "target" level of institutional ownership in the firm's equity.

The substitutability arguments suggest that institutional ownership should have a negative coefficient in the debt and managerial ownership equations. This would be consistent with the hypothesis that firms with greater institutional monitoring require less debt leverage and managerial ownership concentration to control agency costs of the firm.

\section{Functional Form of the Model}

$\mathrm{y}=\mathrm{By}+\Gamma_{\mathrm{x}}+\mathrm{u}$

where $y=(y 1, y 2, \ldots, y p)$ is a set of endogenous or joint dependent variables,

$\mathrm{x}=(\mathrm{x} 1, \mathrm{x} 2, \ldots, \mathrm{xq})$ is a set of exogenous or predetermined variables uncorrelated with the error terms,

$\mathrm{u}=(\mathrm{u} 1, \mathrm{u} 2, \ldots, \mathrm{up})$, and

$\mathrm{B}$ and $\Gamma$ are parameter matrices.

A typical feature of the above model is that not all $\mathrm{y}$-variables and not all $\mathrm{x}$-variables are included in each equation.

A necessary condition for identification of each equation is that, for every y-variable on the right side of the equation, there must be at least one x-variable excluded from that equation. There is also a sufficient condition for identification, the so-called rank condition.

The estimated coefficients are always larger in the ordinary least squares (OLS) model compared to the 2SLS models. This supports the hypothesis that OLS estimates of coefficients have a positive bias in simultaneous equation models (simultaneity bias). Contrarily, 2SLS estimated coefficients tend to have downward bias. 
In a system comprising of independent endogenous variables, the 2SLS method is preferred over the ordinary least squares (OLS) method as the latter would lead to biased and inconsistent parameter estimates as discuss above. An important assumption of the OLS model is that the error term is uncorrelated with each of the regressors. This implies that the explanatory variables are all pre-determined or are determined outside the system. It is very clear that this is not the case here because the debt ratio and managerial ownership are exogenous to the system. This is why it would be inappropriate to assume that the error term in the debt (managerial ownership) equation is uncorrelated with the managerial ownership (debt) variable appearing as a regressor.

Thus, use of the OLS model under these conditions, will produce estimates that are bias and inconsistent (Dutta (1975)). The 2SLS model however allows us to see how the managerial ownership decision affects leverage separately from how the leverage decision affects managerial ownership by separating the results into two different decision variables.

2SLS is the improved version of single equation models employed in some recent studies that examine the agency implications of debt structure Friend and Hasbrouk (1988)), and managerial ownership (Friend and Lang (1988). Friend and Hasbrouk note the potential bias in interpreting their results as a result of possible simultaneous bias in their empirical model. However, a more recent exception is the study by Jensen, Solberg and Zorn (1992). They employed a simultaneous equations approach with debt, managerial ownership, and dividend policy as the endogenous variables. However, they do not further examine the impact of institutional ownership on debt and managerial ownership.

\section{OPERATIONAL MODELS}

The specification of the simultaneous equations system is given as below:

DR $=a_{0}+a_{1}$ ERNVOL $+a_{2}$ DEPR $+a_{3}$ RDAD $+a_{4}$ GROWTH $+a_{5}$ INSTL $+a_{6}$ MGROWN $+u$

MGROWN $=b_{0}+b_{1}$ STKVOL $+b_{2}$ RDAD $+b_{3}$ GROWTH $+b_{4}$ TA $+b_{5}$ INSTL $+b_{6}$ DR $+v$

Debt equation, includes measures of earning volatility (ERNVOL), non-debt tax shields (DEPR), expenditures in intangible assets (RDAD), asset growth (GROWTH), institutional ownership (INSTL), and managerial stock ownership (MGROWN) as regressors. While managerial ownership equation includes stock return volatility (STKVOL), expenditure in intangible assets (RDAD), asset growth (GROWTH), size of the firm (TA), institutional ownership (INSTL), and debt ratio (DR), which is jointly endogenous variable.

\section{OPERATIONAL VARIABLES: DEBT EQUATION}

The first four explanatory variables are included as control variables on the basis of prior studies that investigate the determinants of corporate debt structure (for example, Bradley, Jarrell, and Kim (1984), Titman and Wessels (1988), and Friend and Hasbrouk (1988)). We are only including the variables that have commonly appeared in these studies and to indicate where there is some general agreement as to their theoretical and empirical significance, while at the same time ensuring a parsimonious specification.

The control variables we are using here are most similar to the debt structure model estimated by Bradley, Jarrell, and Kim (1984). However, Bradley, Jarrell, and Kim (1984) do not include an asset growth variable. They also do not examine the effects of institutional ownership and managerial ownership in their debt equation.

We are using the ERNVOL as a proxy for the business risk and the potential for bankruptcy inherent in the firm. For the commonly argued, firms expose to higher business risk tend to have lower debt ratios. Thus, a negative coefficient is expected for the ERNVOL variable.

DEPR is used as a proxy for non-debt-related tax shields available to the firm. DeAngelo and Masulis (1980) in their study show that firms having non-debt-related sources of tax shields, that is depreciation and investment tax 
credits, would utilize less debt. Thus, a negative coefficient for DEPR should be hypothesized. However, there are some previous studies generally find this variable to have a positive coefficient (for example, Bradley, Jarrell, and Kim (1984)). The most common explanation is that a positive sign is consistent with Scott's (1977) secured debt hypothesis. According to Scott, firms can obtain favorable debt terms when secured by tangible assets that are usually associated with higher levels of depreciation.

For the RDAD, Myers (1977) argues that agency costs associated with intangible assets are higher than those associated with tangible assets. From this point of view, we are expected that RDAD should be inversely related to the debt ratio.

In explaining the GROWTH variable, Titman and Wessels (1988) argue that a high growth rate indicates greater flexibility in future investments and offer greater opportunities for expropriating wealth from debt holders. Therefore, we expect GROWTH to be negatively related to the debt ratio. Another explanation is a high growth rate is indicative of the profitability and success of the firm in plowing more resources into the firm. This in turn could be associated with lower information asymmetry costs of equity (Myers and Majluf (1984)) and, hence, a preference for equity over debt financing. This argument would also suggest a negative coefficient for the GROWTH variable.

In the previous discussion, we argued that larger institutional ownerships would create greater monitoring efforts in the firm and consequently restraining the opportunistic behavior by managers. Thus, to mitigate the agency costs of the firm, permitting the firm to utilize less debt. A negative coefficient for INSTL is hypothesized.

Increased in managerial ownership aligns interests of managers with the interest of outside shareholders and reduces the debt. The role of debt here is as an agency-conflict-mitigating device. Friend and Hasbrouk (1988) and Friend and Lang (1988) suggest that corporate insiders have a much greater vested interest in ensuring the continued viability of the firm because of the greater non-diversifiable risk of debt to management than to public investors. Therefore, the larger the stocks own by insiders in the firm, the greater the desire of insiders to minimize capital structure risks. Accordingly, a negative coefficient for MGROWN is expected.

\section{MANAGERIAL OWNERSHIP}

We include stock return volatility (STKVOL), value of intangible assets (RDAD), asset growth (GROWTH), firm size (TA), institutional ownerships (INSTL), and debt ratio (DR) as the explanatory variables for the managerial ownership equation.

In explaining the STKVOL variable, Crutchley and Hansen (1989) and Friend and Lang (1988) argued that because the human capital is tied to the firm, managers would be reluctant to commit their personal wealth to the firms as this greatly diminishes their diversification opportunities. Further, this non-diversification problem becomes more severe as the stock return volatility of the firm increases. The standard deviation of monthly stock returns estimated over five years is used to proxy for total risk to capture this effect. Based on the argument, a negative coefficient for STKVOL is hypothesized.

As the RDAD are characterized by greater agency costs (Myers (1977)), RDAD-intensive firms should be associated with greater insider ownership in equilibrium. Alternatively, Leland and Pyle (1977) suggest that high RDAD firms are likely to have comparatively more positive private information and therefore higher managerial ownership. Thus, a positive coefficient is expected for the RDAD variable.

We are assuming that past asset growth reflects future profitability and growth potential; managers would be less reluctant to invest in the firm's equity. The positive relationship between growth and managerial ownership could stem from informational advantages to insiders about growth prospects of the firm. Managers, because of their better knowledge of projects being undertaken by the firm, would be more inclined than the average investors to invest on the growth prospects. 
TA is included as a control variable. Previous studies have argued that managerial ownership is much greater in smaller firms than in larger firms. As the firm gets larger, a relatively smaller proportion of shares is owned by the directors and managers owing to their limited personal wealth, constraints on personal borrowing, and the diversification problem. Therefore, a negative coefficient for TA is hypothesized.

The optimal proportion of managerial ownership should decline with increasing institutional monitoring. Thus, a negative coefficient is expected for INSTL.

Most of the argument from the recent studies argued that an inverse relationship between managerial ownership and the debt ratio. Thus, a negative coefficient for DR is anticipated.

\section{RESULT AND DISCUSSION}

Two-Stage Lease Square Results

Table 1: Estimated Coefficients for the Debt and Managerial Ownership Equations Using Two-Stage Least Squares Methodology

\section{Panel A:}

Equation 1: DR $=a_{0}+a_{1}$ ERNVOL $+a_{2}$ DEPR $+a_{3}$ RDAD $+a_{4}$ GROWTH $+a_{5}$ INSTL $+a_{6}$ MGROWN $+u$

\begin{tabular}{|c|c|c|c|c|}
\hline Variable & Coefficient & t-Statistic & Prob. & Sig. \\
\hline ERNVOL & -7.516 & $-3.918 *$ & 0.0002 & R-squared $=0.241$ \\
\hline DEPR & -0.358 & $-1.879 * * *$ & 0.0637 & F-statistic $=4.439 *$ \\
\hline RDAD & -0.723 & -0.654 & 0.5151 & \\
\hline GROWTH & 1.528 & 1.571 & 0.1200 & \\
\hline INSTL & 1.928 & $2.408 * *$ & 0.0182 & \\
\hline MGROWN & -0.105 & $-2.071 * *$ & 0.0412 & \\
\hline
\end{tabular}

Panel B:

Equation 2: MGROWN $=b_{0}+b_{1}$ STKVOL $+b_{2}$ RDAD $+b_{3}$ GROWTH $+b_{4}$ TA $+b_{5}$ INSTL $+b_{6} D R+v$

\begin{tabular}{|c|c|c|c|c|}
\hline Variable & Coefficient & t-Statistic & Prob. & Sig. \\
\hline STKVOL & 0.123 & 0.388 & 0.6987 & R-squared $=0.216$ \\
\hline RDAD & 0.244 & $1.642 * * *$ & 0.1042 & F-statistic $=3.852 *$ \\
\hline GROWTH & -0.039 & -0.309 & 0.7584 & \\
\hline TA & -0.097 & $-2.217 * *$ & 0.0293 & \\
\hline INSTL & INSTL & $-3.192 *$ & 0.0020 & \\
\hline DR & 0.023 & 1.321 & 0.1901 & \\
\hline
\end{tabular}

Result of the joint estimation of debt policy and managerial ownership are presented at panel A and Panel B of Table 1. The findings suggest that there is a significant impact of institutional ownership which serve as a monitoring device to mitigate agency problem between owner and principal. The institutional ownership variable (INSTL) has the positive predicted sign in the debt equation and is statistically significant at the 0.05 level. However the variable has the negative predicted sign in the managerial ownership equation and is statistically significant at the 0.01 level. The exhibition of positive sign in the debt equation confirm the contention that firm which have good monitoring system may employ higher level of debt financing as debt covenant may discipline the manager opportunistic behaviour in the event of strategic decision making. It is consistent with Jefferis (1988) and Agrawal and Mandelker (1990) who argued that investors especially block-holders provide valuable monitoring services and act as a restrain to opportunistic behavior of managers. The finding of negative and significant association between managerial ownership and debt policy suggest that higher debt policy discourage managerial ownership. Hence debt policy serves as monitoring substitute to reduce agency problem. It could be further explained that the managerial ownership proportionately decrease as debt level increase at the presence of higher institutional ownership which serves as monitoring substitute in limiting transfer of wealth from debt holders to shareholders. 
While result from Panel B suggests that there is a negative and significant relationship between institutional ownership and managerial ownership. This can be argued that as the managerial ownership decreases proportionately as the level of institutional ownership increases. It is becasue institutional ownership fosters additional monitoring and acts as a restraint to the opportunistic behavior on the part of managers. Consequently, the need to utilize managerial ownership to control agency costs is lessened. The finding is consistent with the finding of Agrawal and Mandelker (1990). The institutional ownership which is always come in large blocks may be more capable of monitoring and controlling the management thereby perhaps contributing to corporate performance. This is finding is same as found by Shliefer and Vishny (1986). The weakly significant positive coefficient for DR is similar to that reported by Jensen, Solberg, and Zorn (1992).

In order to ensure the robustness of the result, we included number of control factors (exhogeneous) namely, earnings variability, depreciation to reflect corporate tax shield, research and development expenditure asset size into the system of equations. The coefficient for earnings volatility abbreviated by ERNVOL is negative and statistically significant at the 0.01 level in debt policy equation. The ERNVOL proxy for inherent bankruptcy risk and was expected to be negatively related to the debt ratio. The negative coefficient for ERNVOL is consistent with previous studies which cited an inverse relationship between debt and earnings volatility. The similar results are also documented in BJK (1984), Titman and Wessels (1988), and Friend and Hasbrouck (1988) in their study. The exhibition of significant and negative association between depreciation as non-debt tax shield and debt policy suggest that firm having non-debt related source of tax shield likely utilize less debt.. This is consistent to the non-tax shield hypothesis of DeAngelo and Masulis (1980). The negative coefficient for RDAD in debt policy equation supports Myers' (1977) hypothesis that RDAD intensive firm, because of their greater discretionary investments, incur high agency costs of debt though it is not statistically significant.

However, the coefficient for RDAD appears to be positive and marginally significant at the conventional level with the p-value of .1042 in the managerial equation. This is consistent with Myers' hypothesis that RDAD intensive firms are associated with greater agency costs of debt making managerial ownership a relatively more important device in controlling agency problem of the firm.

The TA variable has the negative predicted sign for the coefficient in the managerial ownership equation and is statistically significant at the 0.05 level. The negative coefficient is consistent with previous studies that document a lower proportion of managerial ownership in larger firms owing to limited personal resources. Weakly significant positive coefficient for DR is similar to that reported by Jensen, Solberg, and Zorn (1992). Consistent with their interpretation, the findings suggest that insider do not choose their ownership level based on debt leverage but the causality goes in the other direction from insider ownership to corporate debt policy.

Generally, the parameter estimates of the managerial ownership and debt equations are consistent with the major hypothesis of the paper that the presence of increased institutional ownership (monitoring) reduces the need for managerial ownership concentration. The coefficients for other explanatory variables are also generally consistent with the agency framework interpretations.

\section{CONCLUSION AND IMPLICATION}

This paper investigates the impact of ownership structure on corporate debt policy in Malaysia. The sample used in this paper is selected from the Bursa Malaysia Composite Index companies which represent the Malaysian capital market.

The early literature suggests that managerial ownership serve to control agency costs of the firm. The literature also indicates that the presence of external monitors acts as a restraint on management's opportunistic behavior. Institutional investors represent one such group of monitoring agents. This study hypothesizes that the managerial ownership are inversely related o the extent of monitoring by institutional investors. Consistent with the main hypothesis of the paper, institutional ownership is found to be negatively related to the level of managerial equity holdings in the firm. Thus the results support the notion that institutional investors serve as effective monitoring agents and help in mitigating agency costs. 
Additionally, the study finds that the debt ratio is inversely related to managerial equity ownership and R\&D expenses. The negative coefficient for managerial ownership in the debt equation supports the notion that these two variables monitoring substitutes in the agency framework.

The estimates for the managerial ownership equation also provide some interesting insights consistent with the agency framework. There is evidence that institutional holdings are inversely related to managerial equity ownership. Further, higher managerial ownerships are associated with increased levels of $R \& D$, which suggest the presence of high agency costs.

While the findings indicate a positive association between size of the firm, which is proxied by average total assets, and managerial ownership it is inconsistent with the general accepted agency theory. The possible reasons that we believe contributed to this phenomena:

- $\quad$ The corporate culture for the most studies come from developed countries. There are some differences between the Malaysian corporate culture and those from the studies, for example the accounting standards and practices.

- $\quad$ The period of study is from 1998 to 2002, which start with the early stage of the 1997 financial crisis. As such the performances of the companies during the period were very volatile subject to the conditions during the period.

\section{REFERENCES}

1. Agrawal, A. and G. N. Mandelker, (1990). Large Shareholders and Monitoring of Managers: The Case of Antitakeover Charter Amendments. Journal of Financial and Quantitative Analysis (June), 143-161.

2. Aoki, M., H. Patrick, and P. Sheard (1994). The role of the main bank in the corporate governance structure in Japan, Japanese main bank system: its relevance for developing and transforming economics (Oxford University Press, Oxford).

3. Berle, A. and G. Means, (1932), The Modern Corporation and Private Property, New Yourk, Macmillan.

4. Bradley, M., G. A. Jarrell, and E. H. Kim, (1984). On the Existence of an Optimal Capital Structure: Theory and Evidence. Journal of Finance (July), 857-880.

5. Cadbury, A., (1992). Report of the committee in the financial aspects of corporate governance. Gee \& Co Ltd, London, December.

6. Coffee, J. C., Jr., (1991). Liquidity versus Control: The Institutional Investor as Corporate Monitor. Columbia Law Review (October), 1277-1368.

7. Crutchley, C. E. and R. S. Hansen, (1989). A Test of Agency Theory of Managerial Ownership, Corporate Leverage, and Corporate Dividends. Financial Management (Winter), 36-46.

8. DeAngelo, H. and R. W. Masulis, (1980). Optimal Capital Structure Under Corporate and Personal Taxation. Journal of Financial Economics (March), 3-27.

9. Fama, E. and M. C. Jensen, (1983). Separation of Ownership and Control. Journal of Law and Economics (June), 301-325.

10. Friend, I. and Hasbrouck, (1988). Determinants of capital structure. Research in Finance 7, 1-20.

11. Friend, I. and L. H. P., (1988). An Empirical Test of the Impact of Managerial Self-Interest on Corporate Capital Structure. Journal of Finance (June), 271-281.

12. Georgen, M. and L. Renneboog, (2000a). Insider control by large investor groups and managerial disciplining in listed Belgian companies. Managerial Finance, forthcoming.

13. Grossman, S. J. and O. Hart, (1988). One share one vote and the market for corporate control. Journal of Financial Economics 20, 175-202.

14. Hermalin, B. E. and M.S. Weisbach, (1991). The effects of board composition and direct incentives on firm performance. Financial Management 20, 101-112.

15. Hoshi, Takeo, K. A., and Gary Loveman, (1994) Financial System Reform in Poland: Lesson from Japan's Main Bank System, Japanese Main Bank System: Its Relevancy for developing and Transforming Economies: pp 592-633. 
16. Huson J. and Shagir, (2003), Managerial ownership concentration and Agency Conflict: A test of managerial ownership, risk taking, debt policy and dividend policy. Paper presented at $5^{\text {th }}$ Annual Symposium of Malaysian Finance Association at Multi Media Univearsity, Malaysia.

17. Jensen, M. and W. Meckling, (1976). Theory of the Firm: Managerial Behavior, Agency Costs, and Ownership Structure. Journal of Financial Economics 3, 305-360.

18. Jensen, M. C. and J. B. Warner, (1988). The distribution of power among corporate managers, shareholders and directors. Journal of Financial Economics (January/March), 3-24.

19. La Porta, R., F. Lopez-De-Silane, and A. Shleifer, (1999), Corporate Ownership Around the World, Journal of Finance, Vol. 52 (July), pp: 1113-1155.

20. Leland, H. and D. Pyle, (1977), Information Asymmetries, Financial Structure and Financial Intermediation, Journal of Finance, 32, pp: 371-387.

21. Lim, M. H., (1981). Ownership and Control of the One hundred Largest Corporations in Malaysia. Oxford University Press, Oxford.

22. McConnell, J. J and H. Servaes, (1990). Additional Evidence on Equity Ownership and Corporate Value. Journal of Financial Economics (October), 595-612.

23. Myers, S. C. and N. S. Majluf, (1984). Corporate Financing and Investment Decisions When Firms Have Information that Investors Do Not Have. Journal of Financial Economics (June), 187-221.

24. Scott, J. H., Jr., (1977). Bankruptcy, Secured Debt, and Optimal Capital Structure. Journal of Finance (March), 1-19.

25. Shleifer, A. and R. Vishny, (1986). Large Shareholders and Corporate Control. Journal of Political Economy (June), 461-488.

26. Shleifer, A. and R. W. Vishny, (1997). A survey of corporate governance. Journal of Finance 52(2), $737-$ 783.

27. Titman, S. and R. Wessels, (1988). The Determinants of Capital Structure Choice. Journal of Finance (March), 1-19.

28. Warner, J. B., R. L. Watts, and K. H Wruck, (1988). Stock prices and top management changes. Journal of Financial Economics 20, 431-460.

29. Wymeersch, E., (1994), Aspects of Corporate Governance. Journal of Corporate Governance 2, 138-149.

\section{APPENDIX}

\section{List Of Sample Study}

1. AFFIN HOLDINGS BHD

2. ALUMINIUM COMPANY OF MALAYSIA BHD

3. AMDB BHD

4. AMMB HOLDINGS BHD

5. AMWAY (MALAYSIA) HOLDINGS BHD

6. BANDAR RAYA DEVELOPMENTS BHD

7. BERJAYA SPORTS TOTO BHD

8. BINTULU PORT HOLDINGS BHD

9. BRITISH AMERICAN TOBACCO (MALAYSIA) BHD

10. CARLSBERG BREWERY MALAYSIA BHD

11. CHEMICAL COMPANY OF MALAYSIA BHD

12. COMMERCE ASSET-HOLDING BHD

13. COMPUTER SYSTEMS ADVISERS (M) BHD

14. COUNTRY HEIGHTS HOLDINGS BHD

15. COURTS MAMMOTH BHD

16. DIALOG BHD

17. DIGI.COM BHD 
18. GAMUDA BHD

19. GENTING BHD

20. GLOBETRONICS TECHNOLOGY BHD

21. GOLDEN HOPE PLANTATIONS BHD

22. GUINNESS ANCHOR BHD

23. HAP SENG CONSOLIDATED BHD

24. HONG LEONG BANK BHD

25. HONG LEONG PROPERTIES BHD

26. HUME INDUSTRIES (M) BHD

27. IGB CORPORATION BHD

28. IJM CORPORATION BHD

29. IOI CORPORATION BHD

30. JAYA TIASA HOLDINGS BHD

31. JOHN HANCOCK LIFE INSURANCE (M) BHD

32. JOHOR PORT BHD

33. JT INTERNATIONAL BHD

34. KIAN JOO CAN FACTORY BHD

35. KIM HIN INDUSTRY BHD

36. KUALA LUMPUR KEPONG BHD

37. KULIM (M) BHD

38. KUMPULAN GUTHRIE BHD

39. LAFARGE MALAYAN CEMENT BHD

40. LEADER UNIVERSAL HOLDINGS BHD

41. LINGKARAN TRANS KOTA HOLDINGS BHD

42. LINGUI DEVELOPMENTS BHD

43. MAA HOLDINGS BHD

44. MAGNUM CORPORATION BHD

45. MALAKOFF BHD

46. MALAYAN BANKING BHD

47. MALAYAN UNITED INDUSTRIES BHD

48. MALAYSIA AIRPORTS HOLDINGS BHD

49. MALAYSIA INTERNATIONAL SHIPPING CORP BHD

50. MALAYSIA MINING CORPORATION BHD

51. MALAYSIAN AIRLINE SYSTEM BHD

52. MALAYSIAN INDUSTRIAL DEVELOPMENT FINANCE BHD

53. MALAYSIAN NATIONAL REINSURANCE BHD

54. MALAYSIAN OXYGEN BHD

55. MALAYSIAN PACIFIC INDUSTRIES BHD

56. MAXIS COMMUNICATIONS BHD

57. MBM RESOURCES BHD

58. MEASAT GLOBAL BHD

59. MESINIAGA BHD

60. MNI HOLDINGS BHD

61. MULPHA INTERNATIONAL BHD

62. NCB HOLDINGS BHD 
63. NESTLE (M) BHD

64. NEW STRAITS TIMES PRESS (M) BHD, THE

65. NIKKO ELECTRONICS BHD

66. NYLEX (M) BHD

67. ORIENTAL HOLDINGS BHD

68. PADIBERAS NASIONAL BHD

69. PERUSAHAAN OTOMOBIL NASIONAL BHD

70. PETRONAS DAGANGAN BHD

71. PETRONAS GAS BHD

72. PLUS EXPRESSWAYS BHD

73. POS MALAYSIA \& SERVICES HOLDINGS BHD

74. PPB GROUP BHD

75. PUBLIC BANK BHD

76. PUNCAK NIAGA HOLDINGS BHD

77. RAMATEX BHD

78. RHB CAPITAL BHD

79. ROAD BUILDER (M) HOLDINGS BHD

80. SARAWAK ENTERPRISE CORPORATION BHD

81. SELANGOR DREDGING BHD

82. SELANGOR PROPERTIES BHD

83. SHANGRI-LA HOTELS (M) BHD

84. SHELL REFINING CO (FOM) BHD

85. SIME DARBY BHD

86. SP SETIA BHD

87. STAR PUBLICATIONS (MALAYSIA) BHD

88. TA ENTERPRISE BHD

89. TAN CHONG MOTOR HOLDINGS BHD

90. TANJONG PLC

91. TELEKOM MALAYSIA BHD

92. TENAGA NASIONAL BHD

93. TIME ENGINEERING BHD

94. TRADEWINDS (M) BHD

95. UDA HOLDINGS BHD

96. UMW HOLDINGS BHD

97. UNISEM (M) BHD

98. UNITED PLANTATIONS BHD

99. WTK HOLDINGS BHD

100. YTL CORPORATION BHD 


\section{NOTES}

